\title{
Els escrits jaumins de l'humanista Bernardí Gómez Miedes (1582 i 1584)
}

\author{
VICENT JosEP ESCARTÍ \\ UNIVERSITAT DE VALÈNCIA/IIFV
}

\section{La historiografia valenciana del Renaixement i el Llibre dels Fets}

És evident, i ja ha estat assenyalat en diferents llocs, que durant els segles XIV i XV la figura del rei Jaume I va ser reverenciada i lloada pels cronistes de la Corona d'Aragó (Belenguer 1984; Ferrando/Escartí 2008). Per altra banda, entre els valencians, a més, la festivació del 9 d'octubre com a data del naixement del país va permetre i potenciar un record permanent, cada any, de la figura reial, maximitzada amb cada celebració centenària. Aquell costum medieval s'allargaria en el temps i ha permés que el record del rei i de la seua crònica s'haja conservat fins als notres dies amb una gran vitalitat.

Però va ser amb el Renaixement i l'afecció dels humanistes pels textos del passat, quan l'obra literària del rei, el Llibre dels Fets, començà a valorar-se més, tot i que, alhora, la imatge del monarca anà assolint una nova dimensió, més o menys secundària per la progressiva incardinació del nostre territori al conjunt dels regnes hispànics governats pels Àustries espanyols. Tanmateix, prova de l'interés dels valencians pel rei fundador del país serà el fet que la primera gran crònica catalana que fou objecte d'una impressió, encara que de manera fragmentària, a València, va ser precisament la de Jaume I. De fet, Lluís Alanya va incloure al seu Aureum Opus (1515) ${ }^{1}$ el fragment que correspon al procés d'ocupació militar del nord del regne i acaba amb la rendició de la ciutat de València al rei conqueridor. En opinió d'Ernest Belenguer (1984: I, 58), això demostraria l'interés en la història regnícola i local per part d'una corporació municipal, i per altra banda mostraria com els jurats de la ciutat tendien a identificar els interessos del cap i casal amb els de tot el regne. En tot cas, aquella actitud del justícia i dels jurats d'aquell temps revela la vigència d'una idea que ja prefigurava el mateix rei en Jaume en dir, al capítol 292 de la seua crònica, que, «puix que havem guanyada València, havíem guanyat tot el regne». A més, el Llibre dels Fets assolia així una nova dimensió $i$ adquiria vigència.

${ }^{1}$ A l'Aurem Opus... s'inclou l'esmentat fragment, i s'indica que ha estat tret «de registre autèntich de l'archiu del Consell de la present ciutat». Del text d'Alanya hi ha edició facsímil (València 1972), i el fragment de la Crònica, en la numeració moderna, ocupa les pp. 17-58. 
Però al llarg del segle XVI, i com ja s'ha destacat en alguns altres llocs (Belenguer 1984: I, 59-67; Ferrando/Escartí 1995: 21-23), les iniciatives dels valencians per recordar el rei Jaume I i la seua obra literària no en varen ser poques, i els testimonis d'algunes d'elles han arribat fins a nosaltres. Així, Pere Antoni Beuter, predicador de la ciutat, va ser l'encarregat de sermonar en la festa del centenar de la Conquesta, el 1538. A més, l'encàrrec de l'homilia, per part de les autoritats, a Beuter, va ser l'origen de la Primera part de la Història de València (València, 1538), segons ens confessa el mateix autor al pròleg de l'obra.

Mossén Beuter indica també com, per tal de fer el sermó de la Conquesta, s'hagué d' "amprar del libre hon està scrita», és a dir, el Llibre dels fets. Tanmateix, en una evident exageració - ben intencionada, per la seua part-, comenta que el text de la Crònica reial «trobí'l en alguns passos que demanava més plena informació y en altres benigna intel-ligència» (Beuter 1998: 39). Evidentment, allò que pretenia el cronista valencià era fomentar la circulació de la seua compilació històrica, malgrat que en ella feia servir unes fonts falsificades a finals del XV, a Itàlia, per un servidor del papa Alexandre VI, i on l'italià pretenia exalçar la península Ibèrica i el projecte de monarquia hispànica dels reis Ferran d'Aragó i Isabel de Castella per damunt i tot de la importància que es reconeixia al passat històric dels italians, que gaudia de l'admiració de tothom, amb el període esplendorós vinculat a l'Imperi Romà. En aquelles mistificacions s'explicava la fundació de les principals ciutats d'Hispània i, entre aquelles, València, però no s'ultrapassava l'època romana. A Beuter, que segurament era conscient d'usar textos de cap veracitat, en qualsevol cas li interessava destacar un passat així de gloriós, per tal de deixar ben cofois als regidors valencians. I en una operació com aquella, a més, s'aspirava a entroncar la història bíblica amb la romana, per enllaçar, després, amb un món que els era més conegut, a partir de les cròniques medievals més o menys solvents (Duran 1991 i Escartí 1998). Beuter, malgrat que a la seua Primera part de la Història de València — que va ser traduïda i augmentada per ell mateix, després, en castellà (Beuter 1546) — arriba només fins als temps immediats a la conquesta jaumina, no s'està d'introduir la figura del rei en Jaume, i ho fa en termes de reverència i d'admiració —l'anomena «ínclit» $i$ «de bona memòria», sovint— $i$ declara que ell mateix arribà a posseir un «trellat», és a dir, una còpia de la Crònica règia que no ha estat comptada fins ara en la llista dels manuscrits coneguts del text jaumí (Escartí 1998: 17).

Tanmateix, també serà a la continuació d'aquell seu primer treball historiogràfic, on Beuter tractarà monogràficament la figura del rei i les seues gestes, precisament a partir del testimoni directe deixat pel rei al Llibre dels Fets. Aquella segona incursió de Beuter al món de la història, adreçada a un mercat més ampli que l'estrictament valencià, s'intitulà Segunda parte de la Corónica general de España, y especialmente de Aragón, Cathaluña y Valencia (València, $1551)$, i això ja resulta prou significatiu del canvi d'orientació que el mateix cronista havia adoptat, tot pensant en un eixamplament dels seus interessos, segurament incentivat per l'èxit de la traducció castellana de la seua Primera part..., redactada en el català local. Aquella segona part en castellà, tornà a editar-se a 
València, el $1604^{2}$, en companyia de la primera, la qual cosa ens parla clarament de l'èxit de l'obra de Beuter, malgrat les crítiques posteriors. I cal assenyalar que la $S e$ gunda parte... és, en gran mesura, una traducció, amb comentaris i anotacions, de la Crònica del rei en Jaume, i Beuter, tot i el canvi de llengua amb intencions polítiques, ideològiques i comercials ben clares —orientades a Castella i la cort dels Âustries—, no s'està de lloar el rei fundador del regne de València. Així, després de relatar la seua mort exemplar, en fa un «plany», que paga la pena de ser reproduït ara i ací, ja que fomenta la visió d'un rei just i ortodoxament creient. I ben mirat, sembla revelar la preocupació de Beuter per la qüestió morisca:

Grandíssimo fue el llanto que por la muerte del santo rey se hizo en todas sus tierras, y assí como las tristes nuevas yvan de mano en mano, assí parecía que una nuve dolorosa y escura cubría los lugares, perdiendo un tan esclarecido rey. Solía, hallándose en fiestas en poblados menores, predicarles a los pueblos él mesmo, informándoles cómo havían de siempre tener su fe en Jesuchristo, Dios y hombre verdadero, y seguir su dotrina con caridad perfeta, esperando en el galardón divinal, por lo qual antes havían de padecer mil muertes que ni un solo fingimiento parecer a los moros ni llegarse a sus ritos o cerimonias. Después de havelles dado dotrina christiana, socorría sus necessidades con las limosnas. ¿Quién le pidió justicia y no se la hizo? ¿Quién quiso d'él merced y se fue vazío? ¿Quién le apellidó, que no le aprovechasse? Rey que más le tenían respeto de padre que de señor, ¿quién no le lloraría? Con los santos tenga Dios su alma en la gloria y en paz aguarden las cenizas de su real cuerpo el día grande de la resurreción para el juyzio de corona en los cielos.

Uns anys després, i per motius probablement polítics (Fuster 1982: 182; i Berger 1987: I, 181-182), eixia a la llum la primera edició completa de la crònica jaumina, a València. Aquella impressió de la Chrònica o Comentaris del gloriosíssim e invictíssim rey en Jacme primer ${ }^{3}$ responia a la petició de l'emperador Carles per al seu nét, el príncep Carles, fill i hereu llavors de qui seria Felip II de Castella, el qual, segons la carta dels jurats de València reproduïda al volum, «seria servit que li enviàssem de ací la Chrònica o comentari del rey don Jacme.» En la carta, els oficials municipals expliquen que, «perquè història tan cathòlica y tant notable no estiga com fins ací oblidada, a molt gran dany de la cosa pública, se ha treballat ab tota vigilància d'estampar aquella en la mateixa llengua materna que per dit rey fonch feta y dictada, a exemple del gran Júlio Cèsar.» El text del rei en Jaume anava acompanyat d'una «taula» de mots considerats «obscurs» per tal de fer-lo més intel-ligible al príncep i, en general, als

${ }^{2}$ De fet, la citació que faig ací és extreta d'aquesta edició de València (1604), reproduïda facsimilarment a Beuter (1995), que no presenta, però, cap paginació.

${ }^{3}$ D'aquella edició se'n feren exemplars amb dues portades diferents. En una se'ns informa que l'edició s'ha fet «per servir ab aquella al sereníssim senyor don Carlos, príncep dels regnes de Castella e infant de Aragó», mentre que en l'altra se'ns dóna notícia que la crònica ha estat «treyta de l'archiu del molt magnífich rational de la insigne ciutat de València hon stava custodiada». Sobre aquella vegeu-ne els diferents treballs introductoris a les seues reproduccions anastàtiques: Sanchis Guarner (1978), Bas Carbonell (1994), Gregori Roig (2007) i Ferrando (2008a). Vegeu també Carrillo (2004). 
lectors regnícoles, que potser ja acusaven, en el pla lingüístic, les dificultats de comprensió d'un text fixat al segle XIV. (Colon 2003 i Ferrando 2008: 41-52). Però hem de pensar que la notícia de l'existència del text reial havia estat portada a la cort dels Austries de manera ben intencionada, segurament pel preceptor del príncep Carles, el valencià Honorat $\mathrm{Joan}^{4}$, que d'alguna manera pretenia fer arribar a aquell món cortesà la idea d'un rei conqueridor i per recordar que, en la concepció d'alguns pensadors, l'anomenada «Reconquesta», encara no estava finalitzada, mentre habitassen els moriscos en territoris hispànics. Una idea que es pot detectar clarament a l'obra historiogràfica de Jaume Bleda, per exemple, de principis del XVII (Vincent/Benítez 2001: 27). En aquella línia de pensament és on la figura del rei en Jaume podia ser ben bé un referent per incentivar l'expulsió dels criptomusulmans.

La mateixa visió panegírica del rei en Jaume és la que en bona mesura s'encarrega de transmetre el també cronista Rafael Martí de Viciana. En efecte, el notari borrianenc, en el seu Libro tercero de la Crónica de la ínclita y coronada ciudad de Valencia y de su reino (València, 1564) ${ }^{5}$, li dedica nombrosos elogis, en fer un resum de la seua vida. Afirma que «fue llamado el bien afortunado, el conquistador, el vencedor y nunca vencido y venturoso, porque todas las jornadas que emprendió de guerras le vinieron prósperas», i repeteix que el «nascimiento fue maravilloso por nascer en la fiesta de la Purificación de la Madre del Señor, y casi a la media noche y con tan divinos successos, e que el nombre Dios se lo dio.» Per altra banda, Viciana, referint-se també — de manera difusa, però- a les fonts d'on beu la informació que reporta, fa constar que

tratan los scriptores de su tiempo que tuvo estas costumbres y excelencias, es a saber, que fue en el ánima buen christiano, benefactor de las iglesias, fue grande de cuerpo, de altaria de nueve palmos, hermoso de rostro, humano, comunicable y benigno, en sus hechos venturoso, siempre vencedor y nunca vencido, amador de virtuosos y amado de sus pueblos, porque con todos se comunicava. Otorgó muchas libertades a sus pueblos y a los que le servían y le seguían en las guerras les dava y repartía casi todo lo que tomava. Y assí, quando más dava más ganava, para más dar a sus criados, vassallos y valedores. Tenía mucho miramiento a quien havía de encomendar los cargos y officios de su casa y de sus reinos. En las dignidades que havía de proveer de personas, primero dentro de sí y después con los de su consejo, hazía el esamen de la vida y fama del otro, tiniendo siempre respecto más a la virtud que a importunaciones. E que jamás se halló hombre que de su presencia y merced se partiesse quexoso, porque tenía este don de Dios, que a los unos con obras y mercedes y a los otros con palabras amorosas, a todos satisfazía.

La descripció del rei, en part, recorda la que va fer Desclot a la seua Cròni$c a$. Però, sobretot, convé destacar com en aquell moment es buscava, potser, la construcció de la imatge d'un príncep just i pròxim al poble, tot el contrari del

${ }^{4}$ Sobre Honorat Joan i el seu interés per Ausiàs March, vegeu Escartí (1997: 59-61). Sobre la seua trajectòria, Campo Muñoz (1986)

${ }^{5}$ Les citacions que faig servir provenen de Viciana (2002: 72, 73 i 78). 
que s'estaven convertint els Àustries espanyols per als valencians en l'època de Viciana, que començaven a sentir-se llunyans. Eren, aquelles, les característiques que es volien per al governant ideal, des dels postul-lats del Renaixement i de l'humanisme cristià, i a teoritzar sobre la figura del príncep va col-laborar algun altre valencià, com ara Frederic Furió i Ceriol ${ }^{6}$.

En aquelles preocupacions intel-lectuals per construir la imatge del príncep es podia encabir perfectament el record de la figura de Jaume I com rei «sant», o digne de veneració i exemplar, que provenia de Muntaner (Ferrando/Escartí 2008: 12-14), era la que des de la intel-lectualitat valenciana i des del mateix poder local s'esforçaven a transmetre i a oferir a la cort espanyola, com a guia i model segur del monarca cristià. I aquell propòsit, en definitiva, també orientarà els esforços del canonge de València, ardiaca de Morvedre i després bisbe d'Albarrasí, l'aragonés Bernardí Gómez Miedes, el qual farà una paràfrasi llatina del llibre de Jaume I, que es publicarà a València el 1582, i després, el 1584, en versió castellana, amb la intenció de servir de llibre de lectura a les futures testes coronades de la monarquia hispànica, com veurem amb més detall. Encara, probablement Miedes influirà i tot, amb els seus textos, en la imatge que sobre el rei Conquistador ens transmetran els cronistes Francesc Diago i Gaspar Escolano, com ja va assenyalar Belenguer (1984: I, 69). Tots dos, per altra banda contribuiran decisivament a fixar i fer perviure la imatge «ideal» del rei Jaume, que, elaborada des de l'Edat Mitjana, havia estat filtrada i amplificada pels nostres cronistes renaixentistes, magnificant el seu vessant guerrer i antimusulmà que convenia a la societat del XVI.

Així, Escolano recull la vida i les gestes del rei en Jaume en els capítols IV$\mathrm{X}$ del Libro Tercero de la Década primera de la Historia de Valencia (València, $1611)^{7}$. Segueix, en general, la mateixa Crònica del rei, de la qual diu que és una «historia» que «el mesmo» va composar «en lemosín», segons la terminologia de l'època. També afirma que la part final del Llibre dels fets hauria estat redactada per un «secretario» que hauria portat a cap «el remate de la historia que el mismo rey andaba escribiendo, de sus hechos». Mossén Escolano, en referir la mort del rei, no oblida fer un elogi del monarca en clau de croada, ja que

reinó casi setenta y tres años, en que entró treinta veces en batalla campal con los moros y los venció siempre. Príncipe verdaderamente digno de inmortal nombre y de ser parangonado con los más aventajados capitanes de todos los siglos, así por su valor militar como por el celo de la religión, pues se cuenta d'él que entre iglesias de fundamento y mezquitas ya hechas dedicadas a la Virgen Nuestra Señora, su gran devota, dejó dos mil.

En opinió de Belenguer (1984: I, 69-71), l'aproximació d'Escolano a Jaume I és «decebedora». Però caldria valorar també, en un autor com aquell, el fet que solament volgué fer una síntesi del seu regnat i, per tant, reeixí en el seu propòsit. Per altra banda, caldria ponderar positivament l'esforç d'Escolano, en fer aquella aproximació al món jaumí (Viciano 1999).

\footnotetext{
${ }^{6}$ Sobre aquell intel-letual, vegeu Furió i Ceriol (1993).

${ }^{7}$ Cite per l'edició Escolano/Perales (1878: 271 i 363).
} 
Per la seua banda, Diago, als Anales del Reyno de Valencia (València, 1613), s'ocupa igualment del regnat de Jaume I i segueix en general el Llibre dels fets, bé que intercalant un bon nombre de documents i altres fonts. Dedica el seu Libro séptimo a aquell període, que ve a representar més de la meitat del volum segon dels Anales publicats. Diago apunta, certament seguint l'edició valenciana del text reial, del 1557, que Jaume I hauria escrit la Crònica imitant Juli Cèsar —amb què el recobria d'un varnís encara humanístic_ — i, després de referir la seua mort, no s'oblida de fer un panegíric de clara orientació antimusulmana, en referència a un problema religiós i social que feia ben poc que havia somoguts els fonaments de la societat valenciana. Per això, Jaume I rebria de Déu,

de su soberana y liberal mano el premio de los trabajos que avía passado en la conquista de los reynos de Mallorca, Valencia y Murcia, en la reducción d'ellos a la fe christiana, en la erección de dos mil iglesias con que los avía illustrado, y en treynta batallas campales que avía tenido contra moros (Diago 1613: I, 392).

A més, per tot allò, calia reivindicar per a Jaume I el qualificatiu de «gloriosíssim» amb què el va presentar l'edició valenciana del Llibre dels fets, de 1557:

Tuvo muy merecido por esso el título de Gloriosíssimo, que es el de mayor grandeza y gloria que se puede dar a un monarcha, y se havía dado en España a los reyes godos. Y con tan justo blasón, y juntamente con el de Invictíssimo le honrraron los que después sacaron a luz la Historia que él propio havía compuesto de sí mismo a imitación de Julio César (Diago 1613: I, 392).

La visió de conjunt que ofereix el dominicà Francesc Diago sobre el regnat de Jaume I, segons Belenguer (1984: I, 74-81), és «excepcional», tot i que se centra únicament en la relació del rei amb el nostre antic regne, però, sobretot, perquè manté una actitud crítica amb les dades no provades referides al rei, ben diferent de la que adoptaren Beuter i Escolano, que acceptaren ingènuament llegendes i tradicions de poca solidesa historiogràfica.

Així la imatge historiogràfica del rei Conquistador, reelaborada durant el Renaixement, es mantindria encara encara durant bona part del segle XVII, i seria vista com un puntal fonamental per tal de recolzar la ideologia de l'expulsió dels moriscos. I és aquella la utilització que en fa el dominic Jaume Bleda a la seua Corónica de los moros de España (1618), on intercala, en traducció castellana, i allà on l'argument li ho demana, fragments del text jaumí. Era, sense dubte, una utilització ben interessada de la crònica jaumina per part d'un dels més acarnissats defensors de l'expulsió dels moriscos, el qual veia en aquella actuació realitzada en bona mesura per la seua tenacitat davant el papa i la monarquia, la fi de la «Reconquesta» de què el rei Jaume I n'era el màxim exponent per als valencians, tal com hem assenyalat més amunt.

Tanmateix, potser per la finalització de l'enfrontament entre cristians i musulmans a les nostres terres, després del 1609, l'interés per la figura del rei en 
Jaume anà descendint relativament $\mathrm{o}$, almenys, passà a ocupar un altre lloc. Ara bé: el segle del Renaixement s'havia encarregat de consolidar i de transmetre a la posteritat una imatge del rei Conqueridor ben concreta, i enmig d'aquella construcció del record de Jaume I com a model de prínceps guerrers i justos, alhora que aferrissat lluïtador contra els musulmans. I és al bell mig d'aquell programa ideològic on cal situar la figura de l'aragonés Bernardí Gómez Miedes.

\section{València a la trajectòria de Bernardí Gómez Miedes}

És evident que, sobre Bernardí Gómez Miedes, en els darrers anys, hem passat de tenir les acostumades biobibliografies a la manera antiga, fruit d'autors com el valencià Josep Rodríguez ${ }^{8}$ o l'aragonés Latassa (1798: I, 481-488), a disposar d'estudis tan rigorosos com el de Sandra Inés Ramos Maldonado (2003: I, XIX-CCLVIII), la qual recull tant les aportacions antigues com les aproximacions més recents i solvents per part d'autors especialistes en l'humanisme aragonés i fins i tot algun estudi encara inèdit ${ }^{9}$. Per tant, ara com ara, gràcies a aquest recent treball, la trajectòria vital de Gómez Miedes pot ser resseguida sense massa dificultats i, especialment, podem veure amb claredat la seua vinculació amb València.

Bernardino Gómez Miedes va nàixer a Alcanyís i si fins ara es pensava que al voltant de 1520 o 1521, Ramos Maldonado (2003: I, XXII-XXIII) afirma que el seu naixement degué produir-se el 1515, tot basant-se, entre altres indicis, en documentació adduïda per J. M. de Jaime (1995: 95-100) on es demostra que Gómez Miedes ja es trobava a la Universitat de València, realitzant els seus estudis, el 1532. Segurament, l'arribada de Bernardí Gómez Miedes al cap i casal del regne de València degué produir-se per l'atracció de la figura d'un oncle seu, Miquel Pérez de Miedes, amb càrrecs a la Seu de València $i$ ardiaca de Morvedre. Aquest darrer càrrec l'heretaria, per cert, el mateix Bernardí. Per altra banda, hi ha constatada la presència a València de dos germans seus, Miquel, doctor

${ }^{8}$ Rodríguez (1747: 550-551) l'inclou entre els «escritores que no siendo valencianos escrivieron algo de nuestra ciudad o de nuestro reyno o sacaron a la luz o exornaron o impugnaron o traduxeron diferentes obras de autores naturales de nuestra provincia», com anuncia al títol d'aquell índex. De Gómez Miedes assenyala el lloc de naixement, els càrrecs a la Seu valenciana, tot que no esmenta que arribàs a bisbe d'Albarrasí. Indica el seu treball sobre les constitucions eclesiàstiques deixades pel seu oncle Miquel Pérez de Miedes i, després de donar les referències bibliogràfiques consultades, adverteix que l'inclou al seu treball «por lo que nos honró con su residencia y nos está honrando con su pluma, y porque en su historia latina (que no dexa de pertenecer por algún lado a este indículo) De vita et gestis Jacobi Expurgatoris, primi regis Aragonum, hablando de la conquista de nuestra ciudad y de nuestro reyno, nos trata a los valencianos con elogios muy honoríficos.» Després, Rodríguez esmena alguna errada detectada en bibliògrafs anteriors, sobre l'autoria de la traducció a l'espanyol i acaba el seu article.

${ }^{9}$ Ramos Maldonado té en compte el treball Castro Gasalla (2000), una tesi que encara no ha vist la llum i que a hores d'ara resulta de consulta impossible. Vull agrair, però, l'amabilitat del professor Luis Charo i del becari Diego Contreras, del Departament de Filologia Clàssica de la Universitat de Cadis, que em varen auxiliar en les meues infructuoses pesquises sobre aquell treball que desitgem veure publicat algun dia. 
en Drets, i Miquel Tomàs, eclesiàstic també i hereu al seu torn de la canongia que arribà a ocupar Bernardí (Chabàs Llorens 1997: 249).

Hem d'assenyalar, per tant, la «valencianitat» de Gómez Miedes, el qual, després de la seua inicial educació infantil a Alcanyís, començaria a formar-se intel-lectualment a les aules de la Universitat de València, on va ser alumne del castellonenc Francesc Jover i del conegut cronista valencià Pere Antoni Beuter (Ramos Maldonado 2003: I, XXVI-XXVIII), el qual segurament li degué transmetre, en part, la passió pels llibres d'Història. No sabem si va arribar a obtenir algun grau, a la universitat valenciana, i Ramos Maldonado (2003: I, XXVI) aporta el parer d'altres autors sobre la qüestió, però el ben cert és que a la portada de la seua obra en castellà sobre Jaume I ens apareix amb el títol de «maestro», sense especificar-hi res més. Per altra banda, en una carta de Llorenç Palmireno a Gómez Miedes, el nomena «eruditissimo viro, Sacrosanctae Theologiae doctori Bernardino Gomez de Miedes» (Ramos Maldonado 2003: I, XLVII). També sabem que va cursar estudis a la Universitat de París, el 1542, i a Lovaina, posteriorment. Des dels Països Baixos va retornar a la Península Ibèrica per mar i el 1548 el trobem iniciant la seua estada a Roma, que es prolongaria per deu anys. A la ciutat pontifícia ens consta que el 1555 intentava la publicació d'una primera versió de la seua obra més coneguda, que portava per títol Commentarii de sale (Ramos Maldonado 2003: I, XXVIII-XXXV). Tanmateix, no es coneix massa sobre la seua estada a Roma, i Ramos Maldonado (2003: I, XXXVI-XL) afirma que «sobre los pasos y andanzas de Gómez Miedes durante estos diez años por tierras italianas poco se sabe», malgrat que aquesta solvent investigadora ofereix dades sobre els personatges a qui va conéixer i amb qui va tractar, de Roma estant, a través de la lectura de les obres de Gómez Miedes. Així, Ramos Maldonado el relaciona a Roma amb el metge català Joan Quintana, entre d'altres. Per altra banda, d'aquella època romana són dues cartes seues conservades, adreçades a Mencia de Mendoza, ja viuda des de feia poc (1550) del seu matrimoni amb el virrei de València, Ferran d'Aragó, duc de Calàbria. Les cartes foren copiades per Jaume Villanueva i una d'elles va ser editada al seu Viage literario a las iglesias de España. Localitzades novament, sembla que contenen «notícies» i serien una mostra dels interessos per l'actualitat més pròxima al canonge de València (Ramos Maldonado 2003: I, XLI). Com s'ha assenyalat en alguns llocs (Ramos Maldonado 2003: I, XLIII-XLIV; i Maestre Maestre 1990: LXXXV-LXXXVI), Mencia de Mendoza hauria exercit un cert mecenatge sobre Gómez Miedes i és segur que el nostre escriptor va mantenir una relació personal amb la casa dels Mendoza, dels quals arriba a descriure costums familiars en algun passatge de la seua obra sobre la sal.

S'ha assenyalat que probablement el retorn de Gómez Mides des de Roma es va produir per la decisió de Felip II de fer retornar als territoris hispànics de la monarquia a tots els estudiants que s'hi trobassen fora, però falta encara per saber si l'amistat de Gómez Miedes amb Mencia de Mendoza influí definitivament perquè, al seu retorn, l'humanista triàs València per tal de fixar-ne la residència. La qual cosa no seria d'estranyar, si tenim en compte l'ànsia d'acostar-se al poder i de medrar que sempre s'ha assenyalat en Gómez Miedes (Ramos Maldonado 2003: I, XLIX-L). En qualsevol cas, des de Roma, i tot pas- 
sant per diversos llocs d'Itàlia, Alemanya i França, Gómez Miedes es va encaminar a València, on ja el tenim localitzat el 1560, encara que va passar algun temps, abans, a Aragó.

La seua presència al cap i casal valencià degué estar, també, en última instància, vinculada al fet de l'ardiaconat de Morvedre, que ja havia detentat un seu parent, com ja hem esmentat. Els ingressos econòmics que tenia a la Seu de València devien ser copioses, i despertaren les lloances dels humanistes coneguts seus, que fins i tot les posaren per escrit: tant Juan de Verzosa com Ruiz de Moros li dediquen alguns escrits, destacant el poder i les rendes de l'ardiaca de Morvedre, encara que el segon no s'està de retraure-li la seua «insana ambició de poder i riqueses» (Ramos Maldonado 2003: I, XLVIII-L). Aquella «ambició» degué ser, sense dubte, la que va fer que el nostre humanista freqüentàs les cases de nobles com el duc de Sogorb, Alfons Ramon Folch de Cardona, o l'arquebisbe de Saragossa i virrei d'Aragó, Ferran, nét del rei Catòlic (Ramos Maldonado 2003: I, L-LI). En qualsevol cas, el seu poder durant els anys 60 del segle XVI degué anar creixent, i la seua fama d'erudit i d'escriptor, que ja corria, s'incrementà més, quan el 1572, a València, va veure la llum, dels taller de Pere de Huete, finalment, la seua primera obra impresa: Comentariorum de sale libri $I V$, dedicats a Felip II. Aquella obra degué ser un èxit, i ens consta que el mateix Gómez Miedes tenia prevista una segona edició, i en aquell sentit ho va comunicar al seu amic i escriptor també, l'aragonés Jerónimo Zurita, cronista, quan, en enviar-li un exemplar de la seua obra, li demanava les esmenes possibles, per tal de millorar-la, en la seua nova edició (Ramos Maldonado 2003: I, LIV).

El 1574, però, Gómez Miedes s'encaminà de bell nou a Roma. En aquella ocasió, segurament per tal de demanar el favor del pontífex amb la intenció de resoldre alguns conflictes de caire econòmic que s'havien generat entre els canonges de la Seu de València i l'arquebisbe, Joan de Ribera. La qüestió de la seua estada a Roma, encara que no fixada del tot, sembla, però, ben plausible, $\mathrm{i}$ es coeixen alguns detalls de l'estada del nostre canonge a la cort pontifícia i comenta, també, la correspondència entre ell i l'arquebisbe de Tarragona, Antoni Agustí. En el retorn a València, l'ardiaca de Morvedre patí les conseqüències d'una tempesta i una part del seu equipatge es va perdre - especialment un manuscrit intitulat De apibus vel republica libri III, encara que no està del tot clar-, però convé assenyalar com el mateix Gómez Miedes faria constar en els seus escrits (Ramos Maldonado 2003: I, LXI) que d'aquell naufragi, per miracle, li arribà a València un baül que contenia sans i estalvis els objectes beneïts per Gregori XIII que li havia regalat el mateix papa. L'anècdota podria ser només una invenció del mateix canonge de València, per tal de guanyar en prestigi davant la societat del seu temps, com ja va assenyalar encertadament Maestre (1990: I, 242).

L'ardiaca de Morvedre, en els útims deu anys de la seua vida es va llançar a una carrera molt més dinàmica, pel que fa a la seua producció literària i també en l'àmbit dels càrrecs eclesiàstics. Així, el 1579 va tornar a publicar, a València, els seus Comentariorum de sale libri V, amb un epigrama laudatori de l'humanista Joan Oliver (Ramos Maldonado 2003: I, LXIV-LXV). Per altra banda, 
el 1582, Gómez Miedes també va publicar un volum, a València, que segurament es basava en un escrit del seu oncle i predecessor en els llocs de responsabilitat a la Seu, Pérez de Miedes, el qual hauria deixat manuscrites unes Constitutiones seu ordinationes Valentiae ecclesiae, que serien el punt de partença de l'Epitome seu compendium constitutionum sanctae metropolitanae ecclesiae Valentinae. L'obra, de caràcter purament «tècnic», hauria estat feta per l'encàrrec del mateix capítol de la Seu, si fem cas de les paraules proemials de Gómez Miedes; i aquella edició, per altra banda, va ser dedicada a l'arquebisbe Joan de Ribera (Ramos Maldonado 2003: I, LXV).

Aquell mateix any 1582, Gómez Miedes va veure eixir, de les premses valencianes de la viuda de Pere de Huete ${ }^{10}$ els De vita et rebus gestis Jacobi primi, regis Aragonum, cognomento «Expurgatoris», libri $X X$. El text, en llatí, és una paràfrasi de la Crònica del rei en Jaume — que s'havia posat en circulació a València, novament, amb l'edició ja esmentada del 1557- i amb afegits provinents d'altres autors, com ara Zurita, que havia publicat els seus Anales de la Corona de Aragón el 1562 i els seus Indices el 1578. Els De vita... serien, al seu torn, dos anys més tard, el 1584, publicats una altra vegada, però ara en castellà, amb el títol de La historia del muy altro e invencible rey don Jayme de Aragón, primero d'este nombre, llamado «El Conquistador» ${ }^{11}$, amb afegits i retocs, com assenyala el seu mateix autor, i com veurem més avall. Els dos textos historiogràfics de Gómez Miedes foren dedicats respectivament als prínceps heureus successius Diego — Jaume_ - i Felip, fills de Felip II. Aquell acostament sistemàtic a la corona i segurament també la seua proximitat al poderós arquebisbe Ribera, li varen aprofitar perquè el mateix 1584 el rei el proposàs per a bisbe d'Albarrasí, i el 1586 en fos consagrat, en una cerimònia que recull el Llibre d'antiquitats de la Seu de València, i que segurament ha passat desapercebuda als investigadors que s'han aproximat a Bernardí Gómez Miedes (Libre... 1994: I, 248). L'acte, amb tot el seu lluïment i l'assistència del més florit de la societat valenciana $\mathrm{i}$, en especial, dels seus representats més poderosos dins l'estament eclesiàstic, sembla que significava en certa mesura el cim de la carrera de Bernardí Gómez Miedes. Tanmateix, l'any següent, i en qualitat de bisbe de la diòcesi aragonesa, encara assolí una nova distinció en ser nomenat diputat a les Corts d'Aragó (Ramos Maldonado 2003: I, LXIX-LXX). Poc abans de la seua mort, el nostre humanista donà a la impremta, ara a Saragossa, una obra que estava destinada a assolir una certa fama. Es tractava del Manual contra la gota, dedicat al mateix Felip II, que també patia aquell mal, i on es contenen una «serie de consejos prácticos y reflexiones morales, fruto de la experiencia literaria y personal» (Ramos Maldonado 2003: I, LXX). El text, que no és un tractat mèdic, pretenia, possiblement, continuar afalagant a la monarquia, per tal de seguir el nostre autor augmentant en honors i en càrrecs, però la mort li so-

10 La viuda de Pere de Huete —o Pedro de Huete- era, també, i anteriorment, viuda de Joan Mey. Com a viuda del segon, el 1557, portà avant l'edició de la Crònica de Jaume I, el 1557. Sobre aquesta edició cal consultar l'estudi més actual i complet, a càrrec de Ferrando (2008). Sobre la impressora, Jerònima Galés, i sobre la seua trajectòria professional, la dels seus dos esposos i la dels seus fills de cognom Mey, encara resulta molt útil el treball de Serrano Morales (1899).

11 Sobre aquesta edició, vegeu Escartí (2008b). 
brevingué accidentalment, el 4 de desembe de 1589, en enfonsar-se l'edifici on es trobava, per causa d'una gran ventada que va provocar l'assolament de part de la ciutat d'Albarrasí (Ramos Maldonado 2003: I, LXXI).

\section{Intencionalitat i opinió a la Historia del rey Don Jayme de Gómez Miedes. Sobre la llengua dels valencians}

El 1582, sembla que de manera «espontània» i a iniciativa personal de l'autor, perquè no ens consta cap interés per part dels regidors valencians, Bernardí Gómez Miedes veia eixir a la llum l'edició de la seua paràfrasi llatina de l'obra memorialística del rei Conqueridor, de les premses de la viuda de Pere de Huete, la tipografia de la qual — pertanyent a la família Mey— havia estat durant anys l'encarregada de les iniciatives oficials de la ciutat i encara ho seria durant un cert temps. El text anava, però, dedicat al príncep Diego o Jaume, fill de Felip II de Castella. A aquest darrer ja havia adreçat Gómez Miedes la segona edidició dels Comentarii de sale (Ramos Maldonado 1999: 300) i sembla prou evident que amb aquelles maniobres el canonge de València volia acostar-se $\mathrm{i}$ promocionar-se a la cort dels Àustries. No anem a entrar a comentar aquell text en llatí ciceronià de Gómez Miedes ${ }^{12}$ fent translació i versió de les paraules de Jaume I a la seua Crònica, segurament a partir de l'edició de 1557 que amb tota probabilitat va manejar i que va ampliar amb els prèstecs de les obres del seu amic Jerónimo Zurita, com ja han assenyalat anteriorment altres investigadors (Ayala Martínez 2000: 215). Però sí que pot resultar interessant veure algunes qüestions. Com ara, que a través dels textos proemials de Gómez Miedes a aquell seu escrit historiogràfic, es pot detectar com era entesa la seua tasca, de cara al seu receptor directe, l'esmentat príncep hereu de la monarquia hispànica, que llavors comptava uns set anys ${ }^{13}$. De fet, si a l'epístola al lector Gómez Miedes fa una captatio benevolentiae i comenta les obligacions dels escriptors i dels lectors, quan han d'enfrontar-se a un escrit, en termes que semblen bastants tòpics, però que posen de relleu la forma de l'autor en concebre el seu treball com a erudit (Ramos Maldonado 1999: 296-298), molt més interessant resulta la praefatio al fill de Felip II. Gómez Miedes aprofita el fet que tant Jaume I com el príncep Diego porten el mateix nom i això li fa augurar-li una fama igual a la del rei medieval al jove hereu que, tanmateix, no tardaria gens a morir. Del rei Jaume I, per altra banda, elogia les seues grans virtuts militars i el seu gran valor, per damunt de tots els personatges del món antic i coetanis d'ell - excepte el rei Lluís de França. També, Jaume I, en la presentació de Gómez Miedes al fill de Felip II, esdevé el fonament de l'imperi hispànic dels Âustries: «non Aragonensis tantummodo, sed totius Hispaniensis Imperii solus fundamenta posuit». Gómez Miedes fa esment del rei Pere, conquistador de Sicília, de Jaume II, que incorpora Sardenya a la Corona d'Aragó, d'Alfons el Magnànim,

12 Ens remetem a la investigació de Castro Gasalla (2000), on suposem que es troben recollides totes les qüestions pertanyents a una edició crítica com l'anunciada al títol de la tesi que, ara com ara, no és d'accés públic.

13 Tenim en compte, ací, l'anàlisi que sobre aquells textos ha realitzat Ramos Maldonado (1999: 295-298 i 300-302). 
conquistador de Nàpols, i de Ferran el Catòlic, que el reincorpora a la corona. També es refereix a la conquesta de Milà per part de Carles V i, encara, esmenta la conquesta de Granada i el descobriment de les terres d'Amèrica. No acaba, però, Gómez Miedes, sense assenyalar les conquestes dels besavis del príncep Diego, per part de la branca portuguesa, i finalitza el seu elogi amb la lloança de Felip II, amb qui es tancava, de moment, la línia dels reis descendents de Jaume I. Després, l'autor fa una valoració positiva del seu propi treball, per haver redactat aquells vint llibres on es conté la vida del rei aragonés «tanquam in speculo contemplanda, atque imitanda proponeremus». De manera que la versió llatina de la Crònica de Jaume I esdevé, així, «espill de prínceps» i recupera, en certa manera, la seua inicial funció de llibre destinat als familiaras i descendents directes del rei Conqueridor, en tant que la seua vida i la seua experiència era proposada com «exemplar» i digna d'imitació.

El fet de traduir el text de Jaume I al llatí hauríem d'entendre'l com una clara operació adreçada a elevar el Llibre dels fets a la categoria d'un clàssic antic i, per altra banda, a dotar-lo d'universalitat, en un intent que no era desconegut als historiògrafs valencians del XVI, que ben aviat optaren pel castellà, en molts casos, amb aquella mateixa intenció (Escartí 2003 i Ferrando 2003). Per altra part, potser Gómez Miedes va dividir el seu escrit en vint llibres, amb la intenció de fer-lo de lectura més fàcil al príncep, tot i que aquells llibres, com que no presenten títols orientadors, es veuen necessitats d'un Index rerum memorabilium que va elaborar l'autor i que permet al lector moure's amb una relativa facilitat per l'obra.

Però Gómez Miedes no solament volia congraciar-se amb la monarquia, i és per això que dedica algunes pàgines de collita pròpia a remarcar les virtuts de la ciutat i de les terres de València i, també, de les seues gents i del seu govern municipal. De fet, a més d'una succinta descripció del cap i casal del regne (Gómez Miedes 1582: 206), exalça la fertilitat de les seues terres i fins i tot lloa la salubritat dels vents que airegen València, el Túria i l'Albufera, que és comparada amb Egipte, en un intent més d'ennoblir amb un vernís de classicitat les coses locals. Per altra banda, hi ha una lloança dels «fruits» de la terra i de la previsió dels jurats de la ciutat (Gómez Miedes 1582: 206-237). Menció a banda mereix la seua reflexió sobre les diferències entre els aragonesos, els catalans i els valencians (Gómez Miedes 1582: 237-238), que repeteix i amplia en la versió castellana d'un parell d'anys després.

Però aquell seu treball en llatí segurament no arribà allà on l'autor pretenia, o no li va reportar els beneficis que n'esperava. Molt possiblement, la mort del príncep a qui havia estat dedicat i el fet d'haver-hi un nou príncep hereu li va fer fàcil l'oportunitat d'una nova maniobra d'acostament a la casa reial. El fet és que Bernardí Gómez Miedes, dos anys després, el 1584, veia eixir a la llum, de les premses de la viuda de Pere de Huete de bell nou, la traducció que ell mateix havia enllestit al castellà de la seua paràfrasi llatina, i l'endreçava al nou hereu, el príncep Felip, tot advertint que

aunque a los principios va la historia muy atada con la latina, de manera que parece más traductión que historia por sí, es tanto lo que se ha añadido por toda ella, y también mudado y mejorado en muchos lugares, que dexa de ser traductión y, siendo una misma verdad, haze historia por sí en esta lengua. 
I és cert que en molts llocs s'aparta de la redacció llatina i que l'autor deixa anar en nombroses ocasions la seua pròpia opinió sobre diversos temes. Però a més, a l'epístola dedicatòria de La Historia del rey Don Jayme de Aragon, Bernardí Gómez Miedes justifica el seu afany per traduir el text reial en llatí i castellà al·legant que aquell monarca la deixà escrita «en su lengua corta y peregrina», encara que «tan verdadera y llena de hazañas, quanto falta de eloquencia y ornamento». L'opinió d'un canonge imbuït d'humanisme universalitzant, no podia ser una altra, i és per això que es va esforçar tant per traduir el Llibre dels fets del rei en Jaume «en las dos más generales y más estendidas lenguas que hoy se hallan en el universo: latina y española». De fet, Gómez Miedes, seguint la moda del moment, va considerar que el castellà i el llatí eren les llengües més apropiades per a difondre les seues idees (Ramos Maldonado 2000).

Però també en aquella estratègia de la traducció, Gómez Miedes segurament manifestava la seua voluntat d'historiar una part del passat de la Corona d'Aragó amb la intenció de deixar per escrit la seua visió sobre determidades coses i, encara, d'oferir models per als futurs governants, com no s'està d'assenyalar als pròlegs dels dos treballs. Per altra banda, el fet que Jaume I pogués ser presentat com un heroi cristià, el convertia en un personatge la vida del qual podia ser ben bé objecte d'estudi d'un clergue com Gómez Miedes (Maestre Maestre 1990: 256). Per altra banda, cal assenyalar que en l'operació de les traduccions, a més d'acostar a la reialesa i a la noblesa del XVI un text medieval, el canonge de València pretenia universalitzar el Llibre dels Feits i proposar Jaume I com a model contra el món musulmà que continuava pressionant les costes valencianes i que persistia, a l'interior, amb el problema morisc, que era ben present en aquells anys, com es pot veure fàcilment a l'obra antimorisca de Jaume Bleda, i tal com ja hem apuntat més amunt.

El pròleg de la versió en castellà també paga la pena d'analitzar-lo amb més detall. Així, si bé és cert que repeteix alguns dels temes ja exposats en la primera versió llatina, el canvi de destinatari - que ara es nomena Felip, com son pare, Felip II- obliga l'autor a variar l'estratègia d'argumentació. En aquest cas, l'ardiaca de Morvedre se centra en la tasca seua de traductor i n'assenyala els seus dubtes, quan es tracta de fer el trasllat de la seua versió llatina a la castellana - cosa que no havia remarcat en el cas de la llengua original del Llibre dels fets-, i usa també del recurs de la seua condició d'aragonés, que li dificultava, al seu parer, usar el castellà perfectament. Beuter (Escartí 1999: 14) afirma, per exemple:

no es razón que a nadie parezca mal que siendo yo valenciano natural y escriviendo de Valencia, a los regidores d'ella escriva en castellano, lengua estraña para Valencia, por el respeto commún y divulgación mayor en toda España de las gracias que Dios ha concedido a este reyno...

Hi planava, com es pot veure, la inseguretat, pel fet de no ser castellà d'origen, com li esdevé, igualment, a Bernardí Gómez Miedes. I és un tema que també era freqüent en altres autors valencians, i que perviurà fins i tot en els segle següents. De tota manera, aquella preocupació lingüística la resoldrà Gómez 
Miedes, quan declara que les llengües — l'aragonés i el castellà- són molt semblants, per ser filles del llatí.

Paga la pena d'apartar-nos ara del pròleg per comentar algunes reflexions aportades per l'ardiaca de Morvedre, referides al fet d'haver prevalgut el català sobre l'aragonés, en la documentació antiga del regne de València i, en especial, en la redacció dels Furs, al qual tema dedica el capítol VIII del llibre XII: Cómo el rey hizo los fueros del reyno de Valencia en lengua lemosina y se quexaron los aragoneses porque no se escrivieron en la suya (Gómez Miedes 1584: 251). Allà s'afirma que els aragonesos es varen sentir «muy agraviados de que los fueros y leyes de Valencia se escriviessen lengua catalana o limosina, tan obscura y grossera, y que fuera harto mejor en la latina o a lo menos aragonesa». Segons Gómez Miedes, aquella queixa també l'haurien expressada «los castellanos y los demás mercaderes españoles que allí se hallavan, que hablavan casi en la misma lengua de los aragoneses, aborresciendo en grande manera la catalana o lemosina, porque no se podían hazer a ella, ni hablarla más que la caldea». D'altra banda, l'aragonesisme de Gómez Miedes encara va més enllà, quan afirma que són els aragonesos els qui millor poden pronunciar la llengua llatina, per damunt i tot dels castellans, a la llengua dels quals, però, els reconeix «que tienen los conceptos de las cosas más claros, y assí los explican con vocablos más proprios y bien acomodados» però no s'està d'afegir que «de más que por ser de sí eloquentes en el dezir, tienen más graciosa pronunciación que los aragoneses, los quales pronuncian con dientes y labios, y los castellanos algún tanto con el paladar, que les ha quedado del pronunciar de los moros». I ja dins el cos de la seua Historia... insistirà en altres diverses percepcions lingüístiques d'estil semblant (Gómez Miedes 1584: 251-254).

Tornant, però, als textos que encapçalen els llibres de Miedes, cal assenyalar que més atractiva resulta encara la dedicatòria al príncep Felip. Ací, l'hereu és comparat amb Alexandre Magne, en tant que ambdós compartien un pare de nom igual Felip II/Filipo de Macedònia. Després, Gómez Miedes assenyala les cinc majors virtuts que poden ser trobades en un príncep i declara que són difícils de reunir-les en un sol governant. L'excepció haurien estat els reis Ferran III de Castella, el Sant, i Jaume I d'Aragó. Del segon, encara, l'autor fa una lloança per tal de justificar el nom de Conquistador amb què se'l coneix. Novament, Gómez Miedes torna a mostrar al rei en Jaume com a pilar primer de l'Imperi dels Àustries hispànics i fa el mateix recorregut pels monarques que ja hem esmentat més amunt, en tractar del pròleg de la versió llatina. Tot condueix a un nou elogi a Felip II i una valoració del llibre de Jaume I com una lliçó per als prínceps del futur. Gómez Miedes no s'està, també, d'exposar les raons per les quals va traduir l'obra del rei al llatí i al castellà:

pareciéndome que passava muy adelante el descuydo de muchos auctores graves, por no aver puesto las manos en obra tan provechosa, haziendo historia por si de las cosas d'este rey, si quiera por dar sujeto a su tan estendida fama y renombre, que van por el mundo como accidentes sin substancia, me atreví a ponerla a gesto y escrivirla en las dos más generales y más estendidas lenguas que hoy se hallan en el universos: latina y española. En la primera la saqué a luz muy pocos años ha y la dediqué a la felice memoria del esclarecido don 
Jayme, príncipe — que agora lo es mucho más en el cielo—, hermano de vuestra alteza, y que llegó a sus manos la obra, la qual baxo su glorioso nombre se divulgó por toda la Europa; y entendiendo que era accepta a los estraños, parecióme sería tanto más agradable a nuestra España, por ser de cosas acaecidas en ella. Y así, deteminé escrivirla segunda vez en esta lengua, por satisfazer a la importuna demanda de muchos, y mucho más porque vuestra alteza gustasse más presto d'ella.

Gómez Miedes advertia, igualment, d'algunes de les operacions que havia realitzat en aquella nova publicació seua: havia deixat el text repartit en vint llibres, però cada llibre l'havia dividit en capítols «para que con menos trabajo y mayor advertimiento pueda vuestra alteza leerlos». També indica, com ja s'ha esmentat més amunt, que el text «en muchos lugares... dexa de ser traductión y, siendo una misma verdad, haze historia por si en esta lengua». La finalitat de la seua obra, a més, és la mateixa que en el cas de la traducció llatina, i ara ho explicita més encara, si cap. Així, en referir-se a la versió castellana del Llibre dels fets preparada per ell, diu que espera que

vuestra alteza y todos los príncipes del mundo se den a la lición d'ella, para que de pequeños la tomen por espejo y comiencen a preciarse de las quatro más principales y soberanas bondades o virtudes que en él se verán representadas.

Al primer llibre, al capítol inicial, Gómez Miedes (1584: 1-3) ens informa, encara, d'alguns altres aspectes que convé destacar. Justifica el treball pel seu interés en fer conéixer les virtuts del rei en Jaume i que «pueda con el favor divino nuestra lengua y estilo gloriosamente divulgarlas por todas partes a do llegó su fama». A més, diu que «me pareció no era justo que tales y tan señalados hechos que hasta aquí la historia escrita por el mismo rey y por los de su tiempo tenián como encerrados debaxo su corta lengua lemosina, dexassen de comunicarse a las gentes» $\mathrm{i}$ afegeix que les seues traduccions a les llengües llatina $\mathrm{i}$ castellana les va fer «pos ser las dos más estendidas y comunicables». Per altra part, ens presenta un rei Jaume que

que se entiende, por relación de algunos de su tiempo, que, muchas vezes andando en batalla hechava la lança a la siniestra y con la diestra tomava la pluma para apuntar lo que después en sus comentarios dilatava... aunque con duro y poco elegante estilo, según el barbarismo de aquellos tiempos.

\section{I finalitza la qüestió dient que}

en aquella era las gentes precisassen poco las letras y mucho menos el artificioso y eloquente modo de hablar, pues no sólo carecían de la buena lengua latina, pero aún de la suya propria eran poco curiosos; y assí la mezcla y confusión de lenguas que entonces havía en los reynos de la corona hazía confuso y bárbaro el proprio lenguage de cada uno.

D'aquella manera, la traducció de Gómez Miedes al llatí i al castellà quedava ben justificada. Però també argumentava a favor de la seua pròpia intervenció en 
el contingut de la seua versió llatina —i de la castellana— amb les següents paraules:

lo que aquí se contare se ha sacado no sólo de la historia que el mismo rey scrivió de su mano, y de los que en vida suya, como testigos de vista, scrivieron d'ella; pero también nos hemos valido de la que los diligentes scriptores de nuestros tiempos han recopilado de los archivios reales, que han rebuelto en los tres reynos de la Corona, todo para más declarar la verdad d'esta historia, prefiriendo siempre la mano del rey a la de todos los demás, por una principal razón que a mi parecer es concluyente: que si está por ley prohibido mentir delante del príncipe, no se puede creer de un tan gran christiano y cathólico como éste, quisiesse dexar los comentarios que hizo para fundamento de su eterno renombre y fama faltos de verdad y para siempre mentirosos.

La Historia... de l'ardiaca de Morvedre era presentada, doncs, com una versió lliure en castellà de la seua obra llatina, ampliada, i que s'havia inspirat al Llibre dels fets i en altres escrits solvents, tot i que es preferia sempre la versió reial a les altres i quan, en bona mesura, les incorporacions alienes no passaven de ser majoritàriament provinents de l'obra historiogràfica de l'aragonés i amic seu, Jerónimo Zurita. De fet, si Gómez Miedes assenyala ja des del pròleg la seua dependència de la primera obra, també en diferents llocs, i de manera més o menys concreta, ens indica com és l'obra de Zurita la font d'on pren determinades informacions. Així, al capítol IX del llibre primer indica: «según hace de todo esto larga relación el coronista Gerónimo Çurita en sus Annales españoles y Índices latinos» (Gómez Miedes 1584: 11-12) per exemple. En altres ocasions les referències són menys clares: «conforman todos los historiadores antiguos y modernos...» (Gómez Miedes 1584: 13).

Però per damunt de préstecs, influències, plagis o paràfrasis, allò que sembla més destacable, i de major interés són les opinions que l'ardiaca de Morvedre deixa anar a la seua Historia... i quina era la visió, per exemple, que tenia aquell aragonés «valencianitzat» de la terra on havia fet gran part dels seus estudis $i$ que, després d'uns anys fora, com ja hem vist, el tornà a acollir, fins que va ser nomenat bisbe d'Albarrasí. Convé assenyalar, també, com fa una comparació entre els tres territoris integrants de la Corona d'Aragó que resulta bastant curiosa (Gómez Miedes 1584: 268-269), atés que diu que la diferència entre els uns i els altres «nasció de los tres tiempos: passado, presente y por venir». Dels aragonesos diu que «de ellos es el tiempo passado», perquè «siempre se glorian de sus antepassados y a respecto de ellos desprecian los presentes ni tienen tanto cuydado de lo por venir». Dels catalans diu que «o por la esterilidad de la tierra que en muchas partes es mal cultivada y delgada, o porque naturalmente son hechos a la templança y provecho y de lo por venir tan solicitos que apenas gozan de lo presente, cúpoles el tiempo venidero». Dels valencians afirma que

por la fertilidad y abundancia de la tierra les es casi presente toda cosa, y que más cuenta hazen de su propria virtud y hazañas que de las de sus antepassados, ni tampoco temen les ha de faltar la gracia de Dios en lo por venir, y por esso gozan de lo presente (...) de donde les viene muchas vezes el ser largos y también pródigos. 
I acaba dient: «lo honesto recahe en aragoneses y lo útil en catalanes. Assí en los valencianos, que saben usar de todo, cabe lo deleytable, y se compadece - como dize Salomón - junto con el buen bivir, el alegrarse.»

Per altra banda, cal dir que el canonge de València es mostra al llarg del seu escrit sempre a favor dels aragonesos, com era lògic. Però igualment podem dir que també és cert que no vol generar suspicàcies entre els valencians, als quals lloa sovint. Així, per exemple, Gómez Miedes (1584: 257-258) dedica un capítol a parlar «de dónde les viene a los valencianos ser valientes en el acometer, y por qué causas el rey les permitió los desafíos, y cómo fue Valencia Roma primero llamada» on explica que als valencians «la saturnina melancolía de los catalanes, sus progenitores, mezclada con lo dulce de la tierra a que son muy dados, se les ha convertido en pronta y marcial cólera». O també en destina un altre sencer a descriure «las excelencias de la ciudad y reyno» (Gómez Miedes 1584: 259-261). De fet, des del capítol XVI al capítol XXV del llibre XII són continuades les reflexions i les lloances sobre les terres valencianes. S'assenyala, en referència a la ciutat de València, la seua singularitat

por la comodidad de su asiento, por la gran templança y suavidad de ayre, por su rica y varia fertilidad de campaña, por su grandeza y muchedumbre de gente, por su trato y infinidad de mercadurías con las proprias y circunvezinas abundancias del reyno, que todo será para más descubrir el lustre y gran ser d'ella.

I, a més, es diu que «su fundación fue muy antigua entre todas las ciudades de España», cosa que ennoblia els orígens dels valencians més encara. Es parla, també de la «sanidad del ayre» i de la puresa de l'aigua del riu Túria, «que según opinión de médicos y se prueva por espiriencia nungún río hay de agua más sana y delgada» (Gómez Miedes 1584: 260-261). Segurament interessat en les obres d'enginyera antigues, l'autor dedica un capítol als «albañares de la ciudad» (Gómez Miedes 1584: 261-262). També redacta un altre capítol sencer tot defensant la bondat de l'estany de l'Albufera «que no es malsano, antes causa muy gran provecho y recreación a los de la ciudad» (Gómez Miedes 1584: 262263) i parla, en el següent «de la gran fertilidad de su vega y de la diversidad de miesses, árboles y frutas, con la artificiosa compostura de sus huertas.» (Gómez Miedes 1584: 263). En el seu afany d'erudició, i malgrat que s'aparta del seu objectiu inicial de narrar la història del rei en Jaume, el canonge de València destina un llarg capítol a descriure, quasi bé com un geògraf, l'«assiento y descripción del reyno y de su gran fertilidad, y cómo se divide en tres regiones, y de las prelacías y ditados que en él se contienen» (Gómez Miedes 1584: 263-265) i continua amb la lloança de «los grandes provechos y commodidades que la ciudad y reyno tienen por la vezindad del mar» (Gómez Miedes 1584: 265-267). No s'està, tampoc, d'assenyalar una de les grans mancances que el regne de València tenia als ulls dels homes medievals i de l'Edat Moderna, i que sempre va causar problemes al cap i casal «la falta de pan y carnes», a la qual objecció s'encarrega ell mateix de contestar, ponderant positivament el comerç entre València i Aragó i Castella (Gómez Miedes 1584: 267-268). Remarca les diferències entre els tres territoris de la Corona d'Aragó, en el passatge que ja hem 
comentat més amunt, i després destina un capítol a parlar de «los ingenios valencianos y cómo por la comparación del azogue se descubre la gran excelencia y fineza d'ellos» (Gómez Miedes 1584: 269-270) en un clar intent de congraciarse amb els intel-lectuals locals, que són proposats com exemple de la resta de la monarquia, quan en parla a l'útim dels capítols del llibre XII (Gómez Miedes 1584: 270-271) que acaba amb una loança final del rei en Jaume com iniciador de totes les bondats de què gaudeixen els valencians, representats en els habitadors del cap i casal, i a la vegada personatge on s'uneixen les virtuts més característiques dels valencians, dels catalans i dels aragonesos, als ulls de Bernardí Gómez Miedes, el qual afirma que

todo lo qual se deve a este buen rey que dio el principio y medios para que esta ciudad siempre fuesse bien governada. Como aquel que participando de la constancia aragonesa y de la templança catalana, se perfficionó con la afabilidad y liberalidad valenciana, y alcançó título y renombre de constantíssimo, prudentíssimo y liberalíssimo (Gómez Miedes 1584: 271).

En definitiva, resulta prou evident que Bernardí Gómez Miedes aprofità els seus coneixements d'erudit i d'humanista per tal de fer una obra historiogràfica sobre el rei Jaume I, però no va deixar l'oportunitat d'expressar les seues opinions i, encara, va intentar, a través d'aquells seus escrits, obtenir el favor dels valencians, dels seus connacionals aragonesos i, també, del rei d'Espanya, cosa que sembla que sí que va aconseguir, atés que el 1585 va ser proposat per a bisbe d'Albarrasí, potser com a pagament als seus esforços redactant conciençuts papers, entre els que no són els de menys vàlua les seues versions llatina i castellana del Llibre dels fets del rei Jaume I, monarca pel qual sent una veritable admiració, fins al punt de proposar-lo, com hem vist, com a model a les futures generacions. Potser, en això, Gómez Miedes també era una síntesi dels trets que ell mateix provava de descobrir en els tres pobles de la Corona d'Aragó: entusiasmat pel passat, com a bon aragonés, prenia a Jaume I com a referent; pensant com un català, volia oferir aquell model per al futur; i sentintse necessàriament valencià d'adopció, es preocupava pel present seu i aspirava $\mathrm{a}$ un lloc destacat en el govern de l'església, cosa que, a la fi, va aconseguir.

\section{BIBLIOGRAFÍA}

Ayala Martínez, Jorge Manuel, Pensadores aragoneses. Historia de las ideas filosóficas en Aragón, Institución Alfonso el Católico - Instituto de Estudios Altoaragonés-Instituto de Estudios Turolenses, Zaragoza, 2001.

BAS CARBonell, Manuel, «Prólogo» a Jaume I, Chrònica o Comentari del gloriosíssim e invictíssim rey en Jacme, Ajuntament de València, València, 1994.

CARRILlo, José Manuel, «Jaume I. Chrònica o Comentari del gloriosíssim e invictíssim rey en Jaume», dins Escriptors valencians de l'Edat Moderna, Acadèmia Valenciana de la Llengua, València, 2004, pp. 278-279.

BELENGUER, Ernest, Jaume I a través de la Història, 2 vols., Edicions 3 i 4, València, 1984.

BERGER, Philippe, Libro y lectura en la Valencia del Renacimiento, IVEI, 2 vols., València, 1987. 
Beuter, Pere Antoni: Primera parte de la Corónica general de toda España, y especialmente del reyno de Valencia, donde se tratan los estraños acaescimientos que del diluvio de Noé hasta los tiempos del rey don Jayme de Aragón, que ganó Valencia, en España se siguieron, con las fundaciones de las ciudades más principales d'ella y las guerras crueles y mutaciones de señoríos que ha havido, Joan Mei, València, 1546.

—, Cròniques de València, a cura de V. J. Escartí, Consell Valencià de Cultura, València, 1995.

—, Primera part de la Història de València, a cura de V. J. Escartí, Universitat de València,València, 1998.

BledA, Jaume, Corónica de los moros de España, Felip Mei, València, 1618.

CAMPO MuÑOz, María Isabel del, Honorato Juan: humanista, maestro de príncipes y obispo de Osma, Cajade Ahorros y Préstamos, Sòria, 1986.

Castro Gasalla, María Paz, Los «De vita et rebus gestis Iacobi I, regis Aragonum, cognomento Expugnatoris, Libr XX» de Bernardino Gómez Miedes. Introducción, edición crítica, traducción, notas e índices, Tesi doctoral inèdita, Universitat de Cadis, 2000.

ChabÀs Llorens, Roc, Índice del Archivo de la catedral de Valencia, Generalitat Valenciana, València, 1997.

Colon, Germà, «La Taula de les paraules difícils de la Crònica del rei En Jaume», dins G. Colon, De Ramon Llull al Diccionari de Fabra. Acostament lingüístic a les lletres catalanes, PAM, Barcelona, 2003, 61-92.

Diago, Francesc, Anales del Reyno de Valencia, 2 toms, Pere Patrici Mei, València, 1613.

DURAN, Eulàlia, «Defensa de la tradició pròpia davant d'Itàlia al segle XVI», dins Miscel·lània Joan Fuster, III, Abadia de Montserrat, PAM, 1991, 246-247.

EsCARTí, Vicent Josep, La primera edició valenciana de l'obra d'Ausiàs March, Fundació Bancaixa, València, 1997.

—, «Intencionalitats polítiques en les cròniques de Pere Antoni Beuter i de Rafael Martí de Viciana», dins Miscel-lània homenatge a Rafael Martí de Viciana en el V Centenari del seu naixement (1502-2002), Ajuntament de Borriana-Biblioteca Valenciana, Borriana/València, 2003, pp. 205-218.

—, «Jaume I i el Llibre dels fets: de l'Edat Mitjana al Renaixement», dins Gómez Miedes, B.: La historia del muy alto e invencible rey don Jayme de Aragón, Generalitat Valenciana, València, 2008, pp. 5-53.

Escolano, Gaspar - Perales, Joan Baptista, Décadas de la Historia de la insigne y coronada ciudad y reino de Valencia. Primera parte. Terraza Aliena y Compañía Editores, València/Madrid, 1878.

FERRANDO, Antoni, «De la tardor medieval al Renaixement: aspectes d'una gran mutació sociolingüística i cultural a través dels Viciana», Caplletra, 34, 2003, pp. 31-53.

—, «L'edició valenciana de 1557 i la Crònica de Jaume I», dins Jaume I, Chrònica o comentaris del gloriosíssim e invictíssim rey en Jacme Primer, Generalitat Valenciana, València, 2008, pp. 5-59.

FERRANDO, ANTONI-EsCARTí, Vicent Josep, «El Llibre dels Fets del rei en Jaume I», dins Jaume I, Llibre dels Fets. Introducció, transcripció i actualització a cura d'A. Ferrando i V. J. Escartí, Afers, Catarroja-Barcelona, 1995, pp. 9-26.

- (2008), «El Llibre dels Fets del rei Jaume I, testimoni excepcional de la naixença del regne de València», dins Jaume I, El Llibre dels Fets. Estudi introductori i moder- 
nització lingüística per A. Ferrando i V. J. Escartí, Institució Alfons el Magnànim, València, 2008, pp. 9-43.

Furió CERIOL, Frederic, El Concejo y consejeros del Príncipe, amb un estudi d'H. Méchoulan, Tecnos, Madrid, 1993.

Fuster, Joan, La Decadència al País Valencià, Barcelona, Curial, 1982.

Gómez Miedes, Bernardino, De vita et rebus gestis Iacobi I, regis Aragonum, cognomento Expugnatoris, libri XX, Pere de Huete, València, 1582.

—, La historia del muy alto e invencible rey don Jayme de Aragón, primero d'este nombre, llamado el Conquistador, Pere de Huete, València, 1584.

Gregori Roig, Rosa María, «La impressió de la Chrònica del Sereníssim rey don Jaume, conquistador», dins Jaume I, Chrònica o commentari del gloriosíssim e invictíssim rey en Jacme, Institut Gil-Albert, Alacant, 2007.

JAIME LORÉN, José María de, «Noticias de tres importantes graduados bajoaragoneses en la Universidad de Valencia», Boletín del Centro de Estudios Bajoaragoneses, VII, Alcanyís, 1995, 95-100.

Latassa y Ortín, Félix de, Biblioteca nueva de los escritores aragoneses, tom I, Joaquín de Domingo, Pamplona, 1798.

Llibre d'antiquitats de la Seu de València. A cura de J. Martí Mestre, 2 vols., PAM, València/Barcelona, 1994.

MAestre Maestre, José María, El humanismo alcañizano del siglo XVI. Textos y estudios de latín renacentista, Universidad de Cádiz, Cadis, 1990.

Ramos Maldonado, Sandra I., «Introducción» a B. Gómez Miedes, Comentarios sobre la sal, edición a cargo de S.I. Ramos Maldonado, 3 vols., Instituto de Estudios Humanísticos -Ed. Laberinto- CSIC, Alcanyís/Madrid, vol. I, 2003, pp. XIXCCLVIII.

—, «Los prólogos de Bernardino Gómez Miedes. II: Contenido y estructura», Excerpta Philologica, 9, 1999, pp. 285-309.

—, «Latín y vernáculo en la obra de los humanistas: los Commentariorum de sale libri V y El manual contra la gota de Bernardino Gómez Miedes», Habis 31, 2000, pp. 447463.

RodríGueZ, Josep, Biblioteca valentina, Josep Tomàs Lucas, València, 1747.

SANCHIS GuARnER, Manuel, «Pròleg» a Jaume I: Chrònica o Comentari del gloriosíssim e invictíssim rey en Jaume (València 1557), Col·legi d'Arquitectes de València, València, 1978.

SERRANO MORALES, José Enrique, Reseña histórica en forma de diccionario de las imprentas que han existido en Valencia desde la introducción del arte tipográfico en España hasta el año de 1868, Imprenta de F. Doménech, València, 1899.

ViCIANA, Rafael Martí de, Libro tercero de la Crónica de la ínclita y coronada ciudad de Valencia y de su reino, a cura de J. Iborra, Universitat de València, València, 2002.

ViCiAnO, Pau, «Mirar el passat amb ulls barrocs: l'Edat mitjana en la Crònica d'Escolano», dins Cabanilles $i$ el Barroc valencià. Actes de les II Jornades Culturals, Saó, Algemesí/València, 1999, pp. 119-127.

VinCENT, BERNARD-BENÍTEZ, Rafael, «Estudio introductorio» a Jaume Bleda, Corónica de los moros de España, Ajuntament de València-Biblioteca Valenciana-Universitat de València, València, 2001. 